\title{
Influence of Material Change of a Single-stage Front Gearbox Drive Shaft on Selected Stren- gth Analysis Parameters
}

Martin Podařil, Ján Majerník

Faculty of Technology, The Institute of Technology and Business in České Budějovice. Okružní 517/10, 37001 České Budějovice.Czech Republic. E-mail: podaril.martin@gmail.com, majernik@mail.vstecb.cz

Contribution is focused on the analysis of power ratios on a drive shaft of a single-stage front gearbox and comparison of design solution of drive shaft using selected materials suitable for shaft production in terms of minimizing gearbox dimensions with respect to maintaining the transmitted power. The aim of the authors is to achieve the smallest possible dimensions of the gearbox shaft by changing the materials from which it is made.

Keywords: gearbox, drive shaft, material, power

\section{Introduction}

Gears are the most widely used transmission mechanisms that divide the supplied energy from the drive machine to the working one. Generally, we include them to the constant gear ratio mechanism that operate on the principle of toothed engagement between two co-operating wheels. The most straightforward design of the transmission mechanism is the straight toothed gear with the direct teeth. The gear ratio of the meshing wheels is determined by the ratio of their pitch circles of the engagement of the teeth. When teeth engage, strokes and vibrations occur throughout the gearbox, that are being spread through the whole mechanism causing it to vibrate. If the vibration amplitude value, that is being considered already in the design of the gear mechanism, is in low nominals, the gear mechanism operates in normal mode. Higher values of the vibration amplitude and the frequency result in a reduction of the lifetime of the entire mechanism as well as the loss of transmitted power. Reduction of these oscillations is possible by using of materials with higher stiffness values that are better resistant to oscillation and reduce its transmission and multiplication. [4][8][9]

Presented contribution is aimed to assess the strength characteristics of the drive shaft on which the pinion is mounted. It is assumed that by using the material for the production of shafts with higher strength characteristics will result into a reduction in its relative flexural deformation and thus better teeth engagement with the reduction of strokes and vibrations during the operation of the gear unit as a whole. [10][12][13]

Gears themselves are one of the most important types of gear mechanisms. The basic principle consists in the gear toothing and immediate touch of the teeth. The basic construction unit for complex mechanisms is a gear (toothed pair). This pair consists of a drive and driven wheel. The main activity of the toothed pair is primarily to create a coupling (kinematic and forced) between two shafts which are relatively close to one another to provide a constant power flow with appropriate torque change transformation.

The gear consists of a set of wheels that have a toothed gear around their periphery. One of the wheels (a pinion) is mostly rigidly connected to the shaft, to form a single unit. Second one is a separate component and is attached to the shaft by a tight pen.

\section{Characteristics of a gear mechanism}

The gearbox itself belongs to toothed gears with a shape contact. It is a mechanical device that allows transfer between the drive and the driven shaft, a technical device that converts rotary motion into a rotary motion with a generally (but not necessarily) different angular velocity and torque.

In general, the front single-stage transmission (see Fig. 1) consists of a drive shaft, which is also referred to as the input shaft. A gear is provided on it, which transmits its rotation speed to the second gear, which is provided on the so-called driven shaft. This shaft is also referred to as the output shaft. The speed on the output shaft is determined by the size of the gears. Both gears are secured with tight pens to ensure that they do not rotate on the shaft. Smooth rotation on the shafts is allowed by bearings. The whole of this gear is stored in the gearbox.

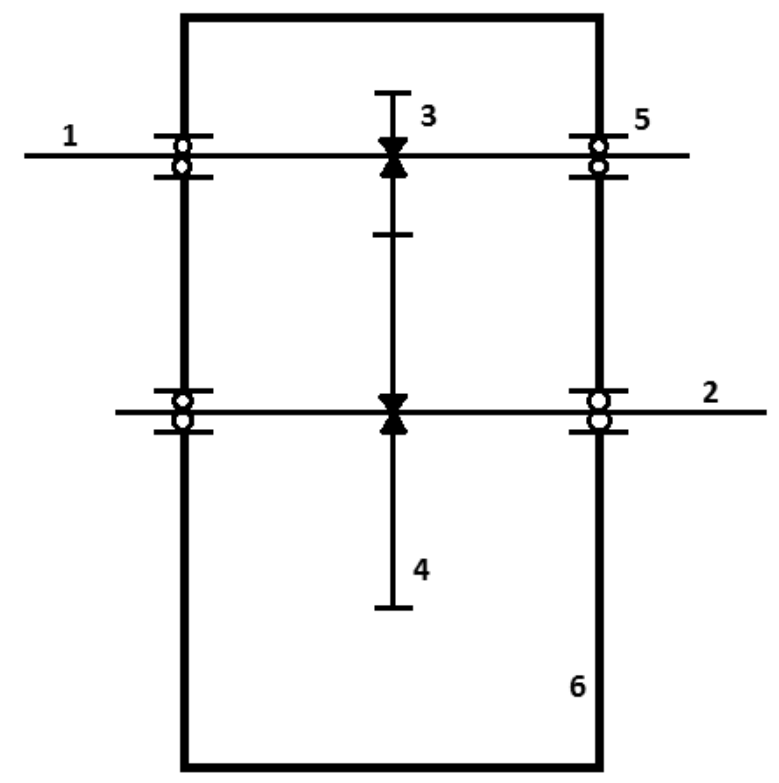

Fig. 1 Single-stage gearbox kinematic diagram 1 -drive shaft with torque $M k_{1}$ and speed $n_{1} ; 2-d r i-$

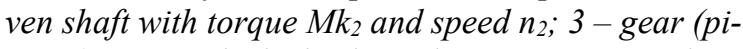
nion); 4 -toothed wheel; 5 - bearing; 6 -gear box 


\subsection{Table of toothed gear dimensions}

The transmission mechanism is designed as a reduction unit connected to the driving station designed for an industrial fan. The required output speed is $n_{2}=365$ rpm. As a drive, the three-phased asynchronous SIEMENS electric motor with a power of $15 \mathrm{~kW}$ and speed $n_{1}=1460 \mathrm{rpm}$ was chosen. From the ratio of the output and input speeds, a gear ratio of 4 was determined.

Tab. 1 Table of toothed gear

\begin{tabular}{|c|c|}
\hline Parameter & Value \\
\hline Number of teeth $\mathrm{z}_{1}$ & 16 \\
\hline Number of teeth $\mathrm{z}_{2}$ & 64 \\
\hline Modulus & 3 \\
\hline Axis distance & $120 \mathrm{~mm}$ \\
\hline Diameter of pitch circle $\mathrm{D}_{1}$ & $48 \mathrm{~mm}$ \\
\hline Diameter of pitch circle $\mathrm{D}_{2}$ & $192 \mathrm{~mm}$ \\
\hline Width of the cogs & $30 \mathrm{~mm}$ \\
\hline
\end{tabular}

\section{Methodology of design of the drive shaft}

The shaft of a gearbox must fulfill its load transfer function and capture the radial and axial forces in the bearings, transfer the load without exceeding the allowable stress and conforming to the technology of the structure. [6]

Designing the shaft, the force ratio analysis was performed, first followed by the equilibrium of the forces in the $\mathrm{X}-\mathrm{Z}$ plane (see Fig. 3) and the $\mathrm{Y}-\mathrm{Z}$ plane (see Fig. 4 ), which are essential for the determination of reduced torque and finaly to calculate the diameter of the input shaft.

\subsection{Designing and verification of shaft}

\section{Force ratio analysis:}

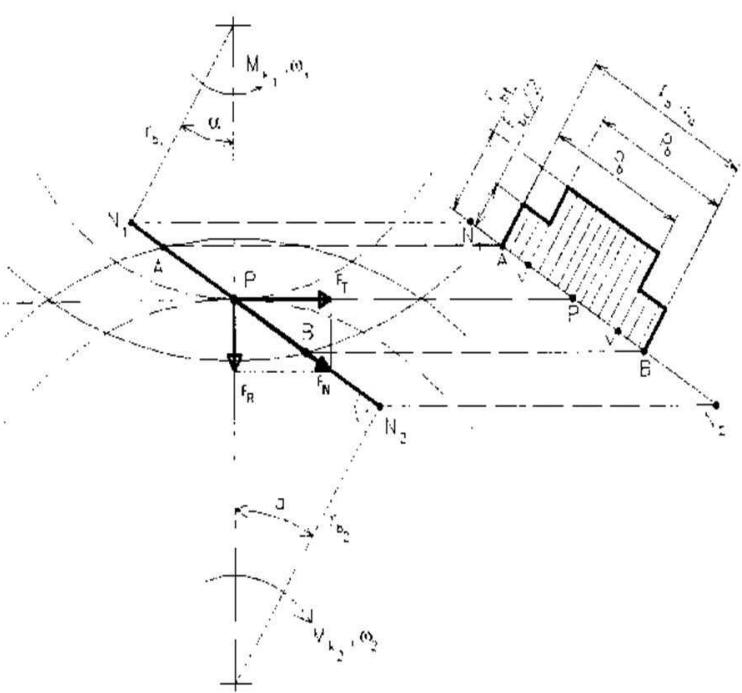

Fig. 2 Force ratios for straight teeth

$$
\begin{aligned}
& F_{T}=\frac{2 \cdot M_{k}}{D} \\
& M_{o_{Z_{2}=0,04}}=760,92 \mathrm{~N} \cdot 0,04 \mathrm{~m}=30,43 \mathrm{Nm}=>M_{o_{\max _{x z}}}=30,43 \mathrm{Nm}
\end{aligned}
$$

$$
\begin{gathered}
F_{R}=F_{T} \cdot \operatorname{tg} \alpha \\
F_{N}=\frac{F_{T}}{\cos \alpha}
\end{gathered}
$$

$\mathrm{F}_{\mathrm{T}}$ - tangential force

$\mathrm{F}_{\mathrm{R}}$ - radial force

$\mathrm{F}_{\mathrm{N}}$ - normal force

$\mathrm{D}$ - the diameter of the pitch circle of the sprocket on the drive and driven shaft

\section{X - Z Plane:}

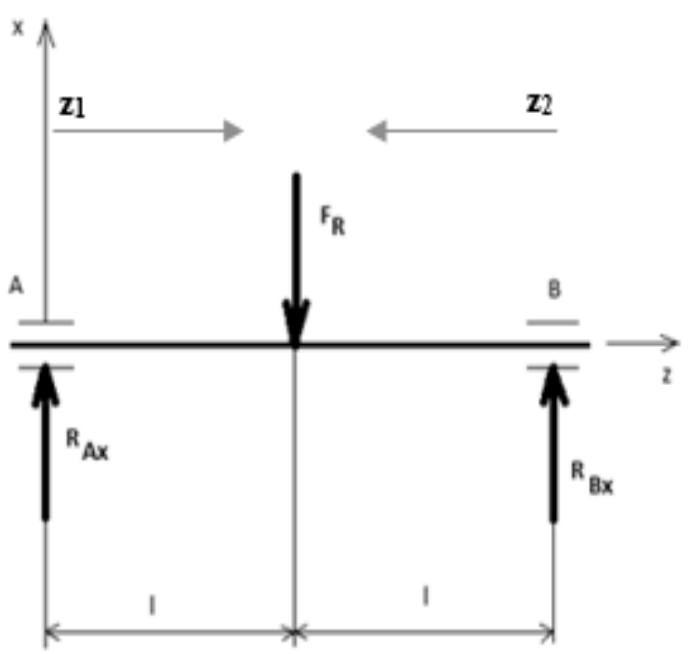

Fig. 3 Force ratio analysis of shaft in the $X-Z$ plane

\section{Calculation of bearing reactions:}

$$
\begin{gathered}
\sum F_{i x}=0 ; R_{A x}+R_{B x}-F_{R}=0 \\
\sum M_{i B}=0 ;-R_{A x} \cdot 2 l+F_{R} \cdot l=0
\end{gathered}
$$

$l=40 \mathrm{~mm}$

Calculation of bending moment:

$$
\begin{gathered}
M_{o_{z_{1}}}=R_{A x} \cdot l \\
M_{o_{z_{1}=0}}=R_{A x} \cdot 0=0 \\
M_{o_{z_{1}=0,04}}=760,92 \mathrm{~N} \cdot 0,04 \mathrm{~m}=30,43 \mathrm{Nm} \\
M_{o_{z_{2}}}=R_{B x} \cdot l \\
M_{o_{z_{2}=0}}=R_{B x} \cdot 0=0
\end{gathered}
$$


Y - Z Plane:

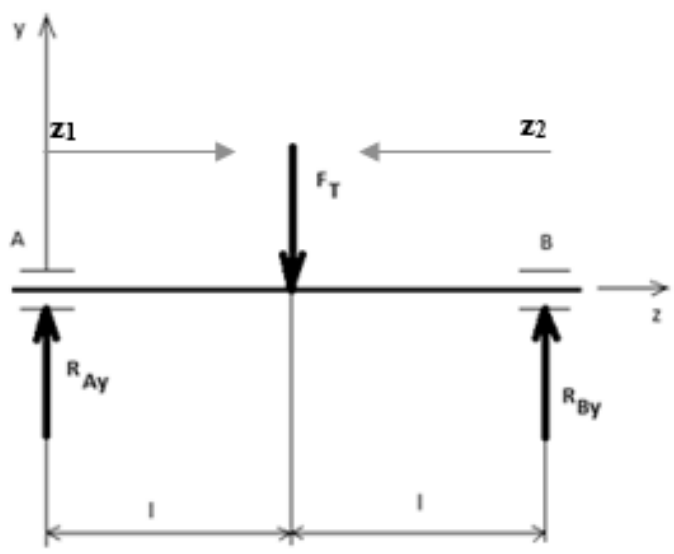

Fig. 4 Force ratio analysis of the shaft in the $Y-$ Z plane

\section{Calculation of bearing reactions:}

$$
\begin{gathered}
\sum F_{i y}=0 ; R_{A y}+R_{B y}-F_{T}=0 \\
\sum M_{i A}=0 ;-F_{T} \cdot l+R_{B y} \cdot 2 l=0
\end{gathered}
$$

$l=40 \mathrm{~mm}$

Calculation of bending moment:

$$
\begin{aligned}
& M_{o_{z_{1}}}=R_{A y} \cdot l \\
& M_{o_{z_{1}}=0}=R_{A y} \cdot 0=0 \\
& M_{o_{z_{1}}=0,04}=2090,62 \mathrm{~N} \cdot 0,04 \mathrm{~m}=83,62 \mathrm{Nm} \\
& M_{O_{z_{2}}}=R_{B y} \cdot l \\
& M_{o_{z_{2}=0}}=R_{B y} \cdot 0=0
\end{aligned}
$$

$$
M_{o_{z_{2}}=0,04}=2090,62 \mathrm{~N} \cdot 0,04 \mathrm{~m}=83,62 \mathrm{Nm}=>M_{o_{\max } \mathrm{mz}}=83,62 \mathrm{Nm}
$$

\section{Design of the shaft diameter:}

Process of designing the shaft diameter is as follows:

1. From the transmitted power and speed, the torque moment $\left(\mathrm{M}_{\mathrm{k}}\right)$ will be determined.

2. Resolving the bending load will determine the maximum bending moment $\mathrm{M}_{\mathrm{o}}$

3. The reduced torque $\left(\mathrm{M}_{\mathrm{red}}\right)$ will be calculated.

4. The diameter of the shaft $\left(\mathrm{d}_{\mathrm{V}}\right)$ in critical crosssection will be determined

$$
\begin{gathered}
M_{o}=\sqrt{M_{o_{\text {max }_{x z}}}^{2}+M_{o_{\text {max }}{ }_{y z}}^{2}} \\
M_{\text {red }}=\sqrt{M_{o}^{2}+0,75 \cdot M_{k}^{2}}
\end{gathered}
$$

\section{Condition of the strength:}

$\sigma_{\text {red }}=\frac{M_{\text {red }}}{W_{o}} \leq \sigma_{d o v}=\frac{R_{e}}{k} ; W_{o}=\frac{\pi \cdot d_{V}{ }^{3}}{32}$

where: $\sigma_{\text {red }}-$ reduced stress

$\sigma_{\text {dov }}-$ permitted tensile stress

$\mathrm{k}$ - safeness

$\mathrm{W}_{\mathrm{o}}$ - cross-section module for bending

$\mathrm{R}_{\mathrm{e}}$ - tensile yield strength

$$
d_{V} \geq \sqrt[3]{\frac{M_{r e d} \cdot 32 \cdot k}{R_{e} \cdot \pi}}
$$

Based on the methodology calculations, the resultant force proportions are mentioned in the Tab. 2. [2]

Tab. 3 lists the minimum allowable values of the drive shaft diameters for the most commonly used materials for the production of shafts for gear units.

The design of relatively short shafts is usually based on the diameter determined by the strength criterion. However, a small torsional stiffness may result, for example, in torsion oscillation, especially for long shafts.
The provisionally calculated shaft diameter covers the full cross-section when grooves for wedges and pens lie beyond. (see Fig. 5) [1]

The drive shaft was designed in program Autodesk Inventor (see Fig. 6), dimensional parameters of the shaft were selected according to the standard (see Fig. 7).

Tab. 2 Resultant force proportions and torques of drive shaft

\begin{tabular}{|c|c|}
\hline Parameter & Drive shaft \\
\hline $\boldsymbol{F}_{\boldsymbol{T}}$ & $4181.25 \mathrm{~N}$ \\
\hline $\boldsymbol{F}_{\boldsymbol{R}}$ & $1521.85 \mathrm{~N}$ \\
\hline $\boldsymbol{F}_{\boldsymbol{N}}$ & $5127.47 \mathrm{~N}$ \\
\hline $\boldsymbol{R}_{\boldsymbol{A x}}$ & $760.92 \mathrm{~N}$ \\
\hline $\boldsymbol{R}_{\boldsymbol{A} \boldsymbol{y}}$ & $2090.62 \mathrm{~N}$ \\
\hline $\boldsymbol{R}_{\boldsymbol{B} \boldsymbol{x}}$ & $760.92 \mathrm{~N}$ \\
\hline $\boldsymbol{R}_{\boldsymbol{B} \boldsymbol{y}}$ & $2090.62 \mathrm{~N}$ \\
\hline $\boldsymbol{M}_{\boldsymbol{x}}$ & $30.43 \mathrm{Nm}$ \\
\hline $\boldsymbol{M}_{\boldsymbol{y}}$ & $83.62 \mathrm{Nm}$ \\
\hline $\boldsymbol{M}_{\boldsymbol{o}}$ & $88.98 \mathrm{Nm}$ \\
\hline $\boldsymbol{M}_{\boldsymbol{r e d}}$ & $124.67 \mathrm{Nm}$ \\
\hline $\mathbf{k}$ & 3 \\
\hline
\end{tabular}

Tab. 3 Minimum allowable values of drive shatf diameters

\begin{tabular}{|c|c|c|}
\hline Material & $\begin{array}{c}\text { Drive shaft } \mathbf{d}_{\mathbf{v}} \\
{[\mathbf{m m}]}\end{array}$ & $\begin{array}{c}\text { Drive shaft } \mathbf{d}_{\mathbf{v}} \text { with } \\
\text { pen slot value } \mathbf{~ t} \\
{[\mathbf{m m}]}\end{array}$ \\
\hline $\mathbf{1 1 7 0 0}$ & 21.3 & 24.8 \\
\hline $\mathbf{1 1 4 2 0}$ & 26.0 & 30.51 \\
\hline $\mathbf{1 2 0 5 0}$ & 22.4 & 26.5 \\
\hline $\mathbf{1 3 2 4 0 . 6}$ & 19.1 & 22.6 \\
\hline $\mathbf{1 5 2 3 0 . 7}$ & 16.8 & 19.7 \\
\hline
\end{tabular}




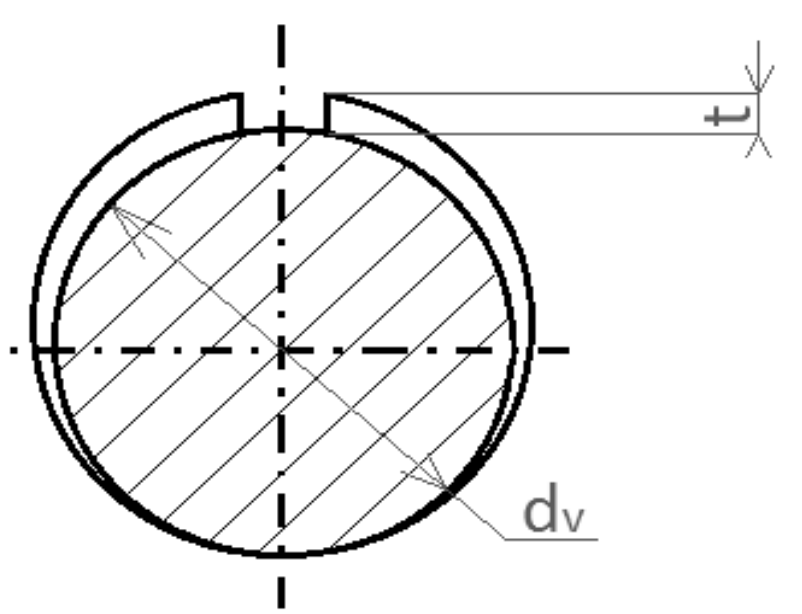

Fig. 5 Pen slot value $(t)[1][3][7][11]$

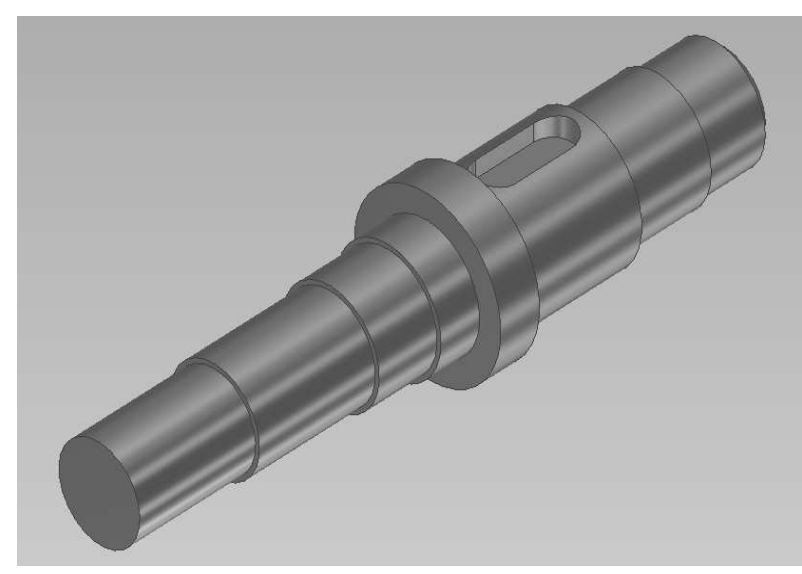

Fig. $63 D$ model of designed shaft in Autodesk Inventor

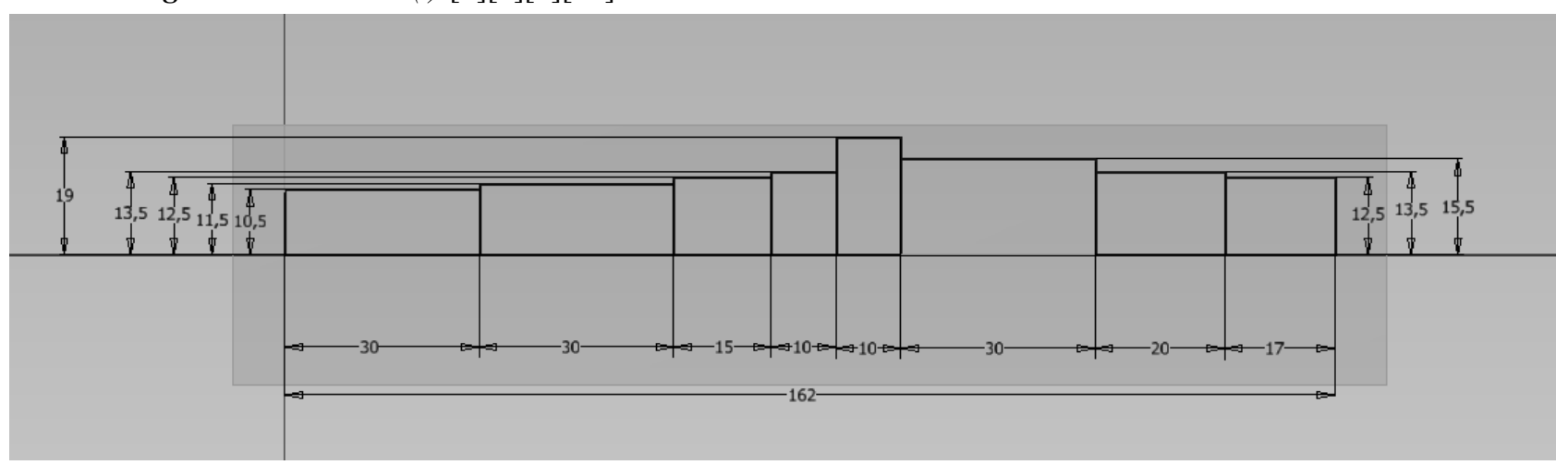

Fig. 7 Dimensions of the drive shaft [mm]

\section{Material analysis}

\subsection{Steel 11420}

It belongs to the carbon, non-alloy structural steels with guaranteed purity and minimum tensile strength and ductility that are being well cold and hot molded. It is very suitable for production of all kinds of semi-finished products, especially machine parts of smaller thickness, statically and dynamically strained as shafts and smaller gear wheels.

\subsection{Steel 13240.6}

Class 13 steels are low-alloy structural steels. They are used where the high-grade carbon steel is not suitable because of its properties and where the chromium steel would be unnecessarily expensive. This steel is well formable and well machinable. However, it is prone to tempering brittleness. It is used for medium-stressed machine parts.

\subsection{Steel 15230.7}

This is an alloy steel with very good hardness and suitable for refining. The advantage is high tensile strength, with guaranteed limit of creep and increased corrosion resistance. It is used for highly stressed parts and machine parts for which high tensile strength and ductility is required, in particular gears, shafts, pinions and torsion bars.

Tab. 4 Characteristics of used materials [5]

\begin{tabular}{|c|c|c|c|c|c|c|c|}
\hline Steel & $\mathrm{R}_{\mathrm{m}}$ & $\mathrm{R}_{\mathrm{e}}$ & $\mathrm{R}_{\mathrm{eK}}$ & $\sigma_{\mathrm{c}}$ & $\tau_{\mathrm{Kc}}$ & $\psi_{\sigma}$ & $\psi_{\tau}$ \\
\hline $\mathbf{1 1 4 2 0}$ & $420-500$ & $200-230$ & 125 & $130-150$ & $75-85$ & 0 & 0 \\
\hline $\mathbf{1 3 2 4 0 . 6}$ & $800-950$ & 550 & 310 & $270-290$ & $150-165$ & 0.1 & 0.05 \\
\hline $\mathbf{1 5 2 3 0 . 7}$ & $1000-1150$ & 800 & 460 & $320-340$ & $185-195$ & 0.2 & 0.1 \\
\hline
\end{tabular}

$R_{m}$-tensile strength [MPa]; $R_{e}$-tensile yield strength [MPa]; $R_{e K}-$ yield strength in shear $[M P a] ; \sigma_{c}-$ fatigue strength to alternating tension and pressure $[M P a] ; \tau_{K c}$-fatigue strength for alternating torsion $[M P a] ; \psi_{\sigma}, \psi_{\tau}-c o e f f i-$ cients of the sensitivity of material to asymmetry of the cycle of tension bending and twisting

\section{Shaft simulation tests}

For a given shaft dimesions a strength analysis of this element in Autodesk Inventor was performed, tracking the three selected materials, which are the most suited for production of shafts for gearboxes. By choosing the material, it was also considered to choose different types of steels, namely unalloyed, low-alloyed and high-alloyed.

The strength analysis was focused mainly on the study of the influence of the material change on the stress and displacement parameters. Following figures and table show the results of the simulation. 


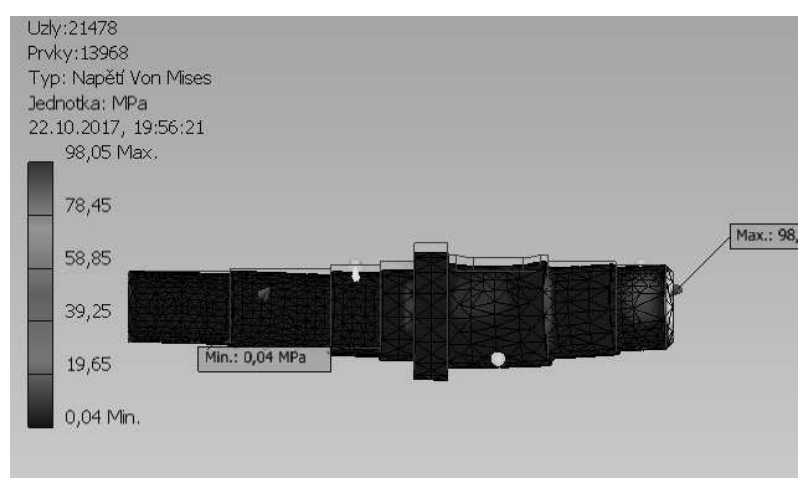

Fig. 8 Drive shaft stress analysis made of material 11 420

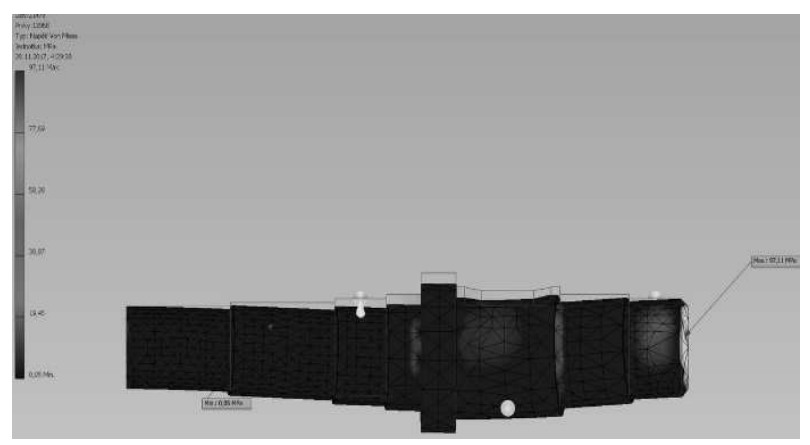

Fig. 9 Drive shaft stress analysis made of material 13240.6

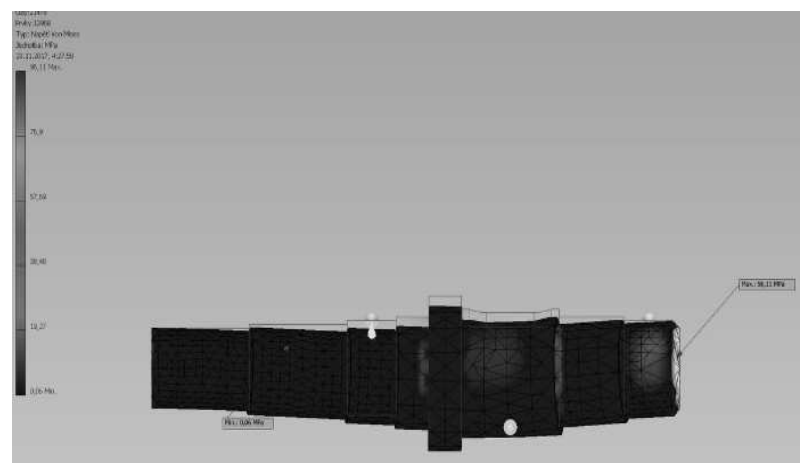

Fig. 10 Drive shaft stress analysis made of material 15230.7

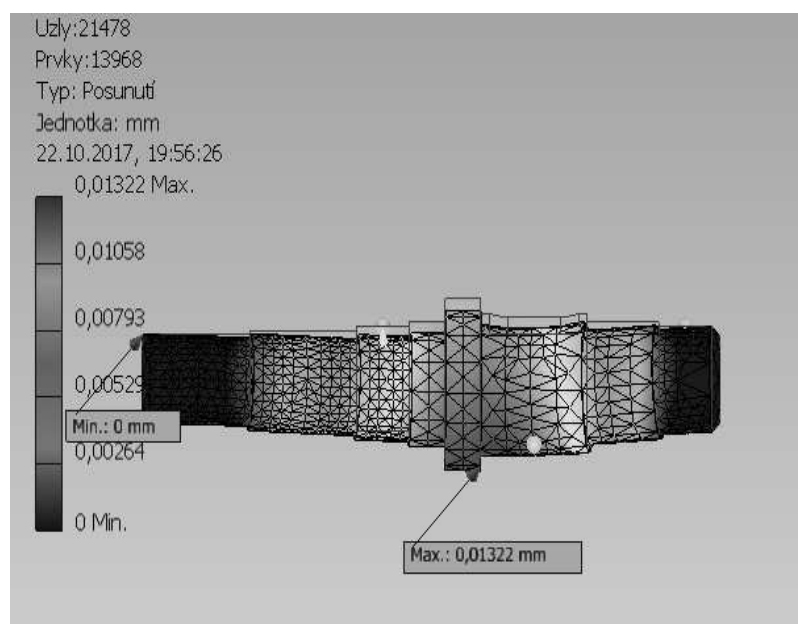

Fig. 11 Drive shaft displacement analysis made of material 11420

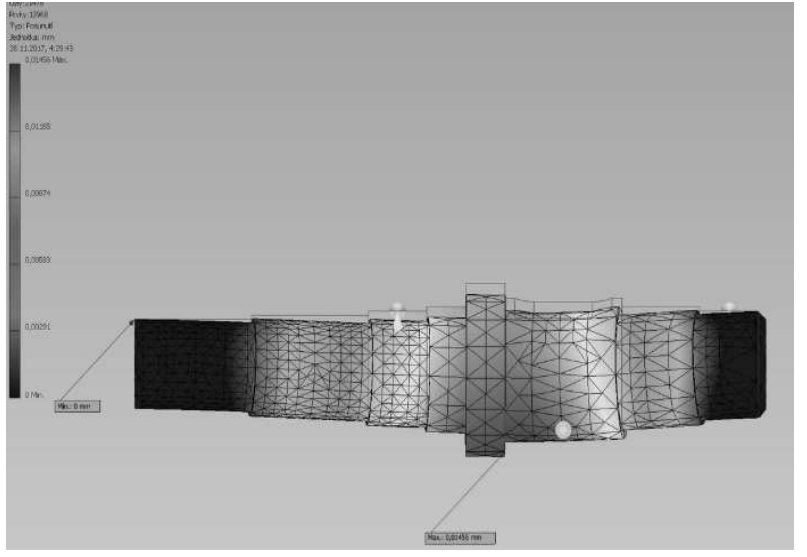

Fig. 12 Drive shaft displacement analysis made of material 13240.6

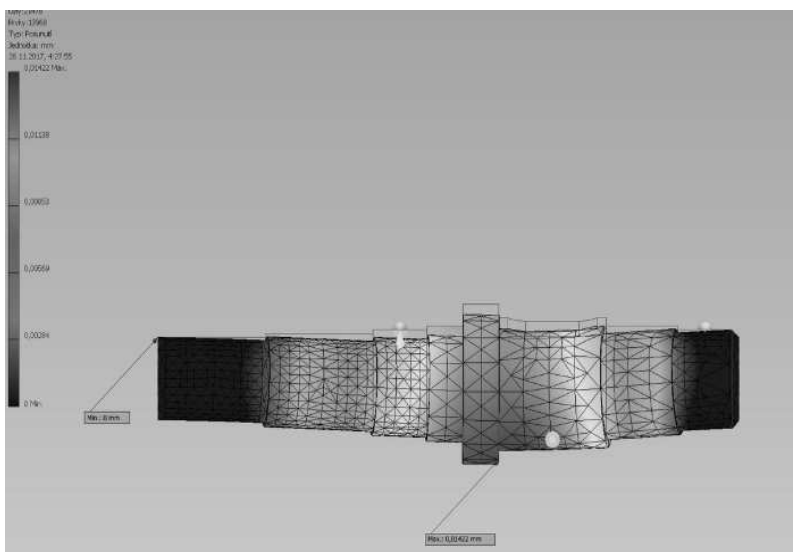

Fig. 13 Drive shaft stress analysis made of material 15230.7

Tab. 5 Maximum values of stress and displacement on the drive shaft

\begin{tabular}{|c|c|c|}
\hline Material & Stress (max.) & Displacement (max.) \\
\hline 11420 & $98.05 \mathrm{MPa}$ & $0.01322 \mathrm{~mm}$ \\
\hline 13240.6 & $97.11 \mathrm{MPa}$ & $0.01456 \mathrm{~mm}$ \\
\hline 15230.7 & $96.11 \mathrm{MPa}$ & $0.01422 \mathrm{~mm}$ \\
\hline
\end{tabular}

\section{Conclusion}

The contribution is focused on the change in strength characteristics of the drive shaft of the transmission mechanism. The design of the gear mechanism was realized for an industrial fan. Based on the numerical calculation, a 3D model of the drive shaft was designed in the program Autodesk Inventor Professional and it was a subject of the strength analysis. According to the analysis, the lowest values of the monitored parameters and thus the highest stiffness showed the material 15230.7 . It belongs to a group of alloy steels and stiffness is being added to it by alloying elements.

The results of the analysis show that for the transmission of torque with simultaneous damping and minimizing the oscillations occuring during the gear engagement, the 15230.7 steel is suitable for the production of the drive shaft in the given gear mechanism type. 


\section{References}

[1] HALKO, J., PAVLENKO, S., (2007). Návrh reduktorov, remeňových a ret'azových provodov. Fakulta výrobních technologií TU v Košicích. ISBN 978-80-8073-956-0

[2] PAVLENKO, S., HALKO, J., MAŠČENIK, J., NOVÁKOVÁ, M. (2008). ČASTI STROJOV II.. 1st ed. 2008. 186 p. ISBN 978-80-553-0103-7.

[3] ŠVEC, V., (1985). Části a mechanismy strojů: Ozubené prevody. Praha: České vysoké učení technické. Fakulta strojní.

[4] KLIMENDA, F., SOUKUP, J., ZMINDAK, M. (2016). Deformation of Aluminium Thin Plate, Manufacturing Technology, Volume 16, (2016), ISSN 1213-2489, 124-129.

[5] LEINVEBER, J., VÁVRA, P., (2008). Strojnické tabulky. Čtvrté doplněné vydání. Úvaly: Albra. ISBN 978-80-7361-051-7

[6] HANDRIK, M., SÁGA, M., PECHÁČ, P., KOPAS, P. (2015). Analysis of Force Conditions of the Hot Forming Machine in Rolling-Out of Bearing Rings, Manufacturing Technology, Volume 15, (2015), ISSN 1213-2489, 821825.

[7] PALÁT, H., (2012). Ozubené převody, základní profil ozubení [online]. 2012 [cit. 2016-03-29]. Dostupné z: http://www.strojka.opava.cz/UserFiles/File/sa-

blony/SPיS_III/VY_32_INOVACE_C-08 05.pdf
[8] IAIN BOYLE, YIMING RONG, DAVID C. BROWN (2011). A review and analysis of current computer-aided fixture design approaches. In: Robotics and Computer-Integrated Manufacturing, Vol. 27, No. 1, pp.1-12.

[9] Ozubené převody. SPSS Olomouc [online]. [cit. 2016-08-11]. Dostupné z: http://www.spssol.cz/ vyuka/PREDMETY/SPS/ozubene_prevody.pdf

[10] MAJERNÍK, J., KMEC, J., GOMBÁR, M., PODAŘIL, M. (2017). The Use of Simulation Programmes for the Structural Analysis and Engineering Optimization of Gating System Structures for Use with High Pressure Die Casting Technology. Manufacturing Technology, 2017, vol. 17, no. 3, p. 343-347. ISSN 1213-2489.

[11] Konstruování strojů: Výroba ozubených kol.: Ústav konstruování [online]. [cit. 2016-08-11]. Dostupné $\quad \mathrm{z}$ : http://old.uk.fme.vutbr.cz/kestazeni/6C2/prednasky/prednaska3_6c2.pdf

[12] SMETANKA, L., ŠŤASTNIAK, P. (2017). Analysis of Contact Stresses of Theoretical and Worn Profile by Using Computer Simulation. Manufacturing Technology, 2017, vol. 17, no. 4, p. 580585. ISSN 1213-2489.

[13] BLATNICKÝ, M., DIŽO, J., ŠTAUDEROVÁ, M. (2017). Strength Analysis of a Structure for Attachment of a Winch on SUV. Manufacturing Technology, 2017, vol. 17, no. 3, p. 291-295. ISSN 1213-2489. 